\title{
A Theoretical Framework on Sustainable Supply Chains: Barriers to Measuring Performance
}

\author{
Alexei Pérez-Velázquez ${ }^{1} \&$ Jorge Laureano Moya-Rodríguez ${ }^{1}$ \\ ${ }^{1}$ Industrial Engineering, Polytechnic Institute, Federal University of Bahia, Brazil \\ Correspondence: Prof. Aristídes Novis Street, 2 - Federação, Salvador, BA, Post Code: 40210-63, Brazil. E-mail: \\ alexei.perez@ufba.br
}

Received: October 20, 2020

Accepted: June 10, $2021 \quad$ Online Published: July 15, 2021

doi:10.5539/jms.v11n2p123

URL: https://doi.org/10.5539/jms.v11n2p123

\begin{abstract}
The direction for the construction of a sustainable supply chain concept has an evolution and contribution of multiple disciplines that have been elaborated by academic and business bias. From this point on, defining a concept of this subject represents an issue that demands an interpretative effort, since several factors and theoretical approaches influence this category. The objective of this article is to demarcate a theoretical framework on sustainable supply chains and relate it to the barriers present in the measurement of sustainable performance. The method applied in this assessment combines systematic literature review, qualitative analysis of content and bibliometrics, through interconnected steps, which allow a detailing of the dimensions and under dimensions of the sustainability in the supply chain and the identification of the barriers that are associated with the measurement of performance. The material considered is supported through theoretical and empirical studies, which approached the formulation of the concepts and their applicability at different levels of the supply chain. This allows the content analysis to demarcate certain stages of development and the different theoretical approaches that respond and assist the concept. The results contribute to the definition of a roadmap to measure of sustainable performance, an issue that is the basis of future studies over this theme.
\end{abstract}

Keywords: theoretical constructs, main barriers, performance indicators, theoretical approach, benchmark method

\section{Introduction}

\subsection{Introduce the Problem}

As a network that integrates physical, information and financial aspects that extends from local to global environments and is responsible for the transfer of resources and value generation, the supply chain is a key and strategic element for today's market (Cooper et al., 1997; Lambert et al., 1998; Mentzer et al., 2001). This is justified by the demand for goods and services in contemporary society. The composition by multiple actors and the distribution in levels of relationship between them represents, in fact, an articulation of a socioeconomic system with values that support culture and synergy of parts of the chain. The points of contact among the supply chain and the environment are inevitable, i.e., at least in some of the initial, intermediate, and final stages there is a reaction between the socio-economic and environmental system with evident contradictions to be considered (Porter \& der Linde, 1995). However, the sources for the conception of new theories about the role of supply chains for environmental issues are one of several justifications for the evolution of this category (Cigolini et al., 2004).

There are motivating sources for change in the macro and micro perspectives that affect the supply chain concept incorporating subjects outside the classic planning/performance lens, which must be analyzed. From macro perspectives, causing a vertical change, are the following issues the climate change, the resources non-renewable, the accumulation of pollution in the ecosystems, the deterioration of the environments surrounding urban and rural regions, among others. A condition critical that has worsened in recent years. From micro perspectives, the changes are derived from the local pressures, such as accountability to stakeholders, social responsibility, and demands for transparency and certification of processes through goods-services with seals and standards of good practice. At this point, the supply chain concept is oriented to incorporate sustainability as a response to the needs demonstrated by the aforementioned issue (Linton et al., 2007). A contributing context was the gradual change in society over the value attributed to the ecological footprint caused by contemporary practices 
(Brundtland et al., 1987), this has determined a work route for the evolution of the concepts of this subject (Tsoulfas \& Pappis, 2008).

\subsection{Explore Importance of the Problem}

The new proposed and proven links about socioeconomic, environmental, technological, and organizational systems for the conceptualization processes required a consensus of multiple theoretical bases. The theoretical evidence considered in the construction of sustainable supply chain concepts, according to Geng et al. (2017), has been established a comprehensive frame of the factors to be considered. This condition defines the guidelines for the revision of the documents that support the theoretical framework of the category that has already been evaluated by Seuring and Müller (2008), Carter and Rogers (2008), Carter and Easton (2011), Sarkis (2012). Nevertheless, each theoretical approach contributes its constructs and thus generates a diffuse scenario in the moment of reaching a sustainable performance model. The group of theories that can be considered exceeds the targets of this study, to focus on the theories such as natural resources-based view, dynamic capabilities, relational, stakeholder, triple bottom line, institutional and transaction cost economic would represent a delimitation for the interpretation of concepts and the definition of a theoretical framework.

The organization of this document is in stages that answered the objective of the study. In a previous phase, the summary and keywords were exposed followed by the introduction which is a provocation to treat this subject. The second stage presents the method and materials needed to conduct the study, which is supported by a procedure for reviewing the documents that must answer the research questions and it define the results of this study. The third stage presents the preliminary results of the selection of documents fulfilling the selection criteria based on the analysis of content and bibliometrics on the selected documents. From the results of the third stage, the answers to the research questions related to the theoretical framework and barriers to measuring sustainable performance may justify. The fourth stage is followed by a discussion and conclusion that are derived from the study.

\section{Method}

This study is carried out through a systematic literature review method, which is chosen as a sample of documents that propose theoretical and conceptual formulations on the sustainable supply chain theme. The study materials should be considered are articles published in journals indexed in bibliographic bases and which represent reference support on the subject. The analysis of content and bibliography are some of the steps of the method, where a characterization of each article is performed about the bibliometric indicators and interconnected with the selected sample of documents. This analysis is defined from the selection arguments focusing on documents that propose and contribute to the category of the sustainable supply chain. Besides, the procedural aspects of the method, it is necessary a stage of exposure of the research questions, which indicate points of interest for this study according to the theoretical framework that it is defined. Finally, to categorize the concepts, which determine bias within the theoretical framework, affiliation to the selected theories, leaders in the fields of studies, collaborative networks that correspond to the structure of knowledge related to the concepts of sustainable supply chains and impact that create the existing barriers in measurement of sustainable performance, and that are arguments to answer the research questions. In this way, the phase of methods and study materials continues with an explanation of the procedure to be applied.

\subsection{Procedure}

The construction of a theoretical framework is carried out from the system of steps, which organize the method to be applied in this study. The elements to be considered initially are the selection of materials that support the systematic review of the literature, which should be theoretical and/or empirical articles with the indispensable condition of proposing a concept about the sustainable supply chain. The following act continues with the analysis of the content (Mayring, 2002, 2014), where the aims of the studies that substantiate the theoretical framework are raised. Also, the theoretical constructs that relate to the object of study are defined. The results are used in a classification framework of the concepts through factor analysis techniques, which defines the relative positions among the concepts within the selected sample.

Subsequently, a bibliometric analysis is performed on the articles to evaluate the previously mentioned indicators. The results of this analysis may be creating the conditions for a second classification. In this case, the documents and references may be considered. The purpose of the classifications is determined by the alignment of each concept to the theory groups and thus define the barriers to measuring sustainable performance in supply chain actors. In this way, the procedure encloses a research strategy for the fulfillment of the objective of this study. This is illustrated through a diagram (See Figure 1): 


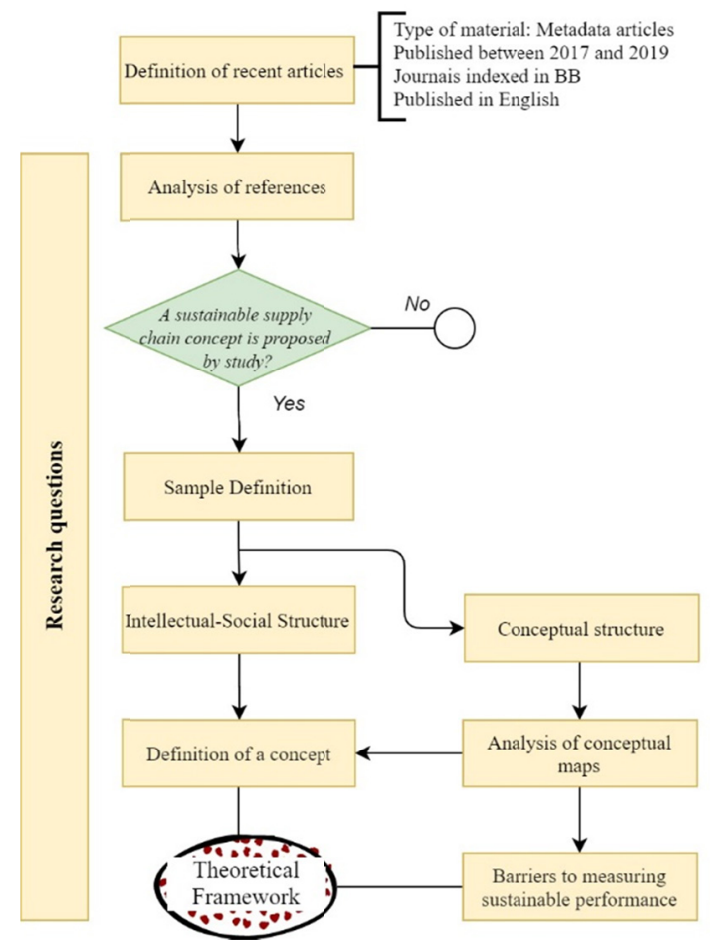

Figure 1. Diagram of the procedure to define a theoretical framework

\subsection{Research Questions}

A theoretical framework on sustainable supply chains is defined necessarily for the analysis goals sample of documents that are fulfilled through literature review. Analysis goals can understand qualities within the knowledge framework that are of research interest. In the face of consolidated studies, such as: Seuring and Müller (2008), Carter and Rogers (2008), Srivastava (2007), Gold et al. (2010), Touboulic and Walker (2015) which provide the category concepts, and it is related to the existing barriers to measuring sustainable performance in chain actors. Therefore, the elements sought in the sample of articles require characterization of the dimensions of the concepts and identification of possible shortcomings in the study area. The research questions are:

$\mathrm{Q}_{1}$ What is the structure present in the sustainable supply chain concepts proposed in previous studies?

$\mathrm{Q}_{2}$ What relationship do the multiple dimensions of sustainable supply chain concept with the measurement of performance?

$\mathrm{Q}_{3}$ What is the weight of the selected theories that underpin SSCM concepts with measurement of sustainable performance?

From the application of the procedure, it is possible to answer each of the questions cited, which includes the theoretical evidence that can support the measurement of sustainable performance.

\section{Literature Review to Build a Theoretical Framework}

\subsection{Conceptual Structure}

The support to obtain results about the theoretical framework begins in this study with the selection of a sample of articles, where certain requirements must be met by the revised documents. The sustainable supply chain category gathers three decades of contributions, which represent an accumulation of concepts and theoretical studies that are available for this type of evaluation. The starting point for the selection of sample articles is the documents published in the period 2017-2019 on this subject. These documents should be metadata type, it is expressed by the systematic literature reviews method, such as Luthra et al. (2017), Ansari and Kant (2017), Maditati et al. (2018), Carter et al. (2019) which provide a starting point for determining study sample that is required (See Table 1). 
Table 1. Metadata type articles and literature reviews.

\begin{tabular}{lll}
\hline References & Study objectives & Sample \\
\hline Luthra et al., 2017 & The proposes a structure to evaluate the sustainable selection of suppliers & 90 \\
Ansari \& Kant, 2017 & $\begin{array}{l}\text { The aims to conduct a new review of the SSCM literature and provide the status of the research } \\
\text { field by classifying and analyzing relevant papers extracted from structured research from } \\
\text { different perspectives }\end{array}$ & 185 \\
Maditati et al., 2018 & $\begin{array}{l}\text { The proposes a comprehensive view of structural associations among the GSCM factors such as } \\
\text { drivers, practical indicators, and performance measures. } \\
\text { Conducting a systematic literature review on sustainable supply chain management (SSCM) in } \\
\text { primary logistics and supply chain management magazines during the period 2010-2018 }\end{array}$ & 87 \\
\hline
\end{tabular}

The studies cited may allow defining an idea about the concept of sustainable supply chains, but they do not reflect some of the positions that have been accumulated in recent years of developments in the category under study. A solution to this problem is determined by the reference systems that support the studies (Luthra et al., 2017; Ansari \& Kant, 2017; Maditati et al., 2018; Carter et al., 2019), which helps to identify metadata type studies for literature review that propose concepts about the object of study. This makes available a population of studies that comprises different biases within the conceptual and theoretical relationship of the sustainability supply chain, which correspond to the different dimensions that make up this concept. The review accounts for 387 references, excluding those repeated by the four studies, and in total only 54 of them present a concept exposure on the category, which represents the sample for the literature review.

The sample documents are: Bowen et al. (2001), Fiksel (2003), Kleindorfer et al. (2005), Linton et al. (2007), Svensson (2007), Srivastava (2007), Seuring and Müller (2008), Font et al. (2008), Carter and Rogers (2008), Hutchins and Sutherland (2008), Pagell and Wu (2009), Haake and Seuring (2009), Gold et al. (2010), Taticchi (2010), Wolf (2011), Woodcraft et al. (2011), Gupta and Palsule-Desai (2011), Carter and Easton (2011), Chi (2011), Faisal (2012), Aboelmaged (2012), Carbone et al. (2012), Ashby et al. (2012), Gunasekaran and Spalanzani (2012), Hassini et al. (2012), Ahi and Searcy (2013a), Muduli and Barve (2013), Hansen and Schaltegger (2013), Harms et al. (2013), Stefan Seuring and Gold (2013), Beske et al. (2014), Brandenburg et al. (2014), Fabbe-Costes et al. (2011, 2014), Beske and Seuring (2014), Blome et al. (2014), Ji et al. (2014), Boukherroub et al. (2015), Tajbakhsh and Hassini (2015), Burritt and Schaltegger (2014), Govindan et al. (2014), Gualandris and Kalchschmidt (2014, 2016), Hsu et al. (2016), Hussain et al. (2016), Idil Gaziulusoy (2015), Kannegiesser et al. (2015), Kim et al. (2014), Kuik et al. (2011), Mangla et al. (2014), Matthews et al. (2016), Pagell and Shevchenko (2014), Schrettle et al. (2014), Su et al. (2016), Carter and Washispack (2018), Fayezi et al. (2018).

The selected documents extend from 2001 to 2018, which summarizes a representative period given the number of studies published on sustainability applied to the supply chain. The most prominent journals were International Journal of Production Economics (6), Journal of Cleaner Production (5), International Journal of Physical Distribution and Logistics Management (4), Journal of Supply Chain Management (3), and Supply Chain Management: An International Journal (3); the remaining journals summarize the total sample selected with two or one articles.

The conceptual structure allows an analysis of the content, which through the semantics of the concepts determines that the centrality is at the end "company", according to the processing of the software Tropes v. 8.4.4, (ACETIC-CYBERLEX \& Investors private, 2020). The reasons that "company" is in this position is related to the weight given in the concepts to the actors of the supply chain to implement sustainable practices. Another point derived from the analysis of the content is the term sustainability, which expresses a hierarchical condition before all keywords used in the concepts (See Figures 2 and 3)

This disregards the links established by the concepts according to the degree of similarity, which should be studied by other techniques for the analysis of content. One technique that would illustrate the particularities of the concepts is the method of multidimensional scaling considering the objects to be compared. In the case of selected concepts, a non-metric scale of similarity between the concepts can be evaluated. In this way, a particular exposition of the concepts is offered. 


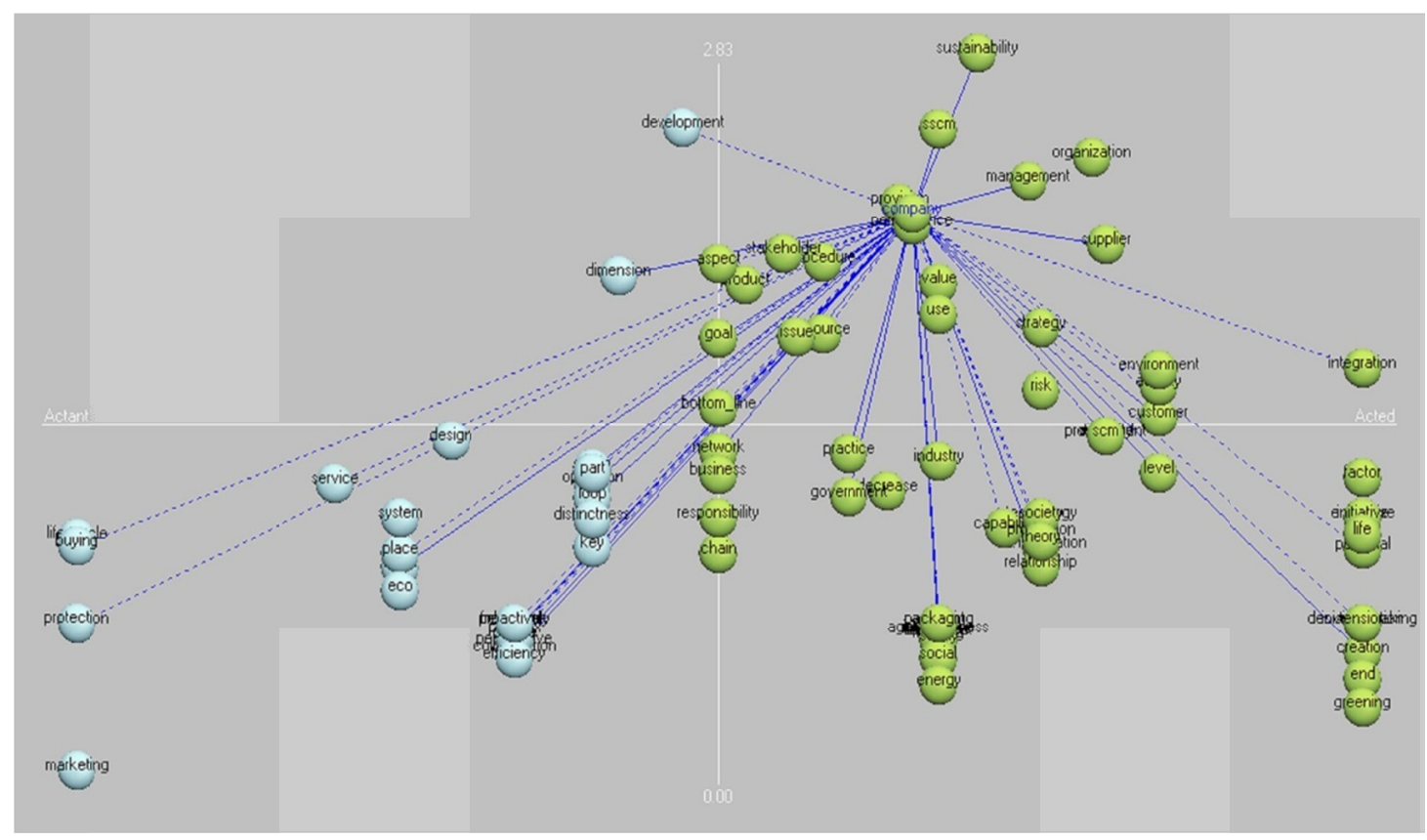

Figure 2. Semantic network of the sample of concepts, (Centrality)

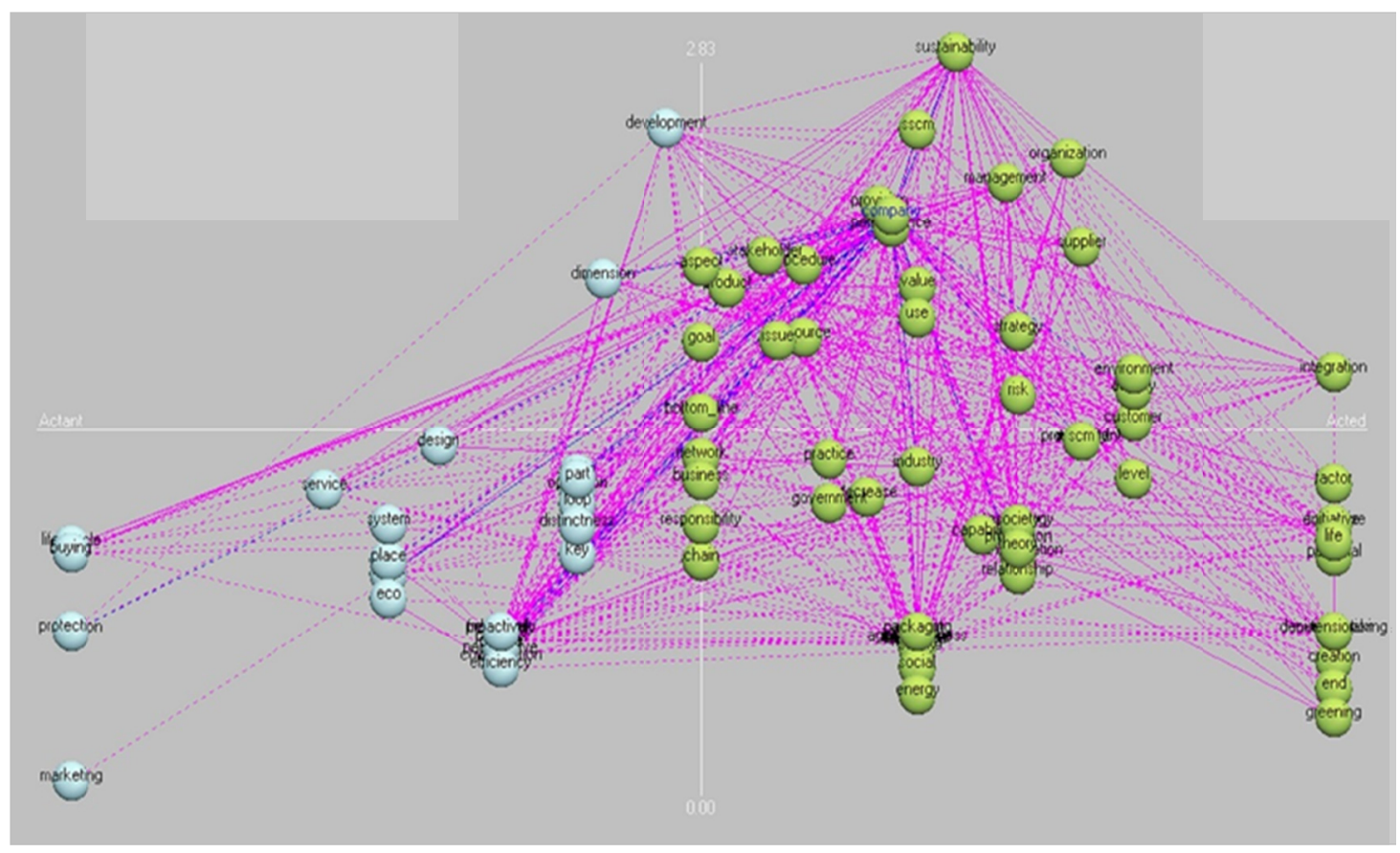

Figure 3. Relationship between the keywords that make up the sample of concepts

From the semantic evaluation, one can compare the concepts by a system of eighty keywords derived from the previous evaluation. This allowed mapping the concepts according to the declarations, orientations, and dimensions considered in themselves. The result is determined in two analysis dimensions, for now, D1 and D2, that will be defined later each one. The procedure considers the distance by the "Binary" method, which provides a distribution of the concepts as follows (See Figure 4).

The relationship between concepts and the eighty keywords allows defining groups of concepts, which can be similar in their definitions. All concepts consider in certain ways that supply chains need sustainability, the combination of factors, dimensions, and objectives of this need is designed in different degrees of incidence. The 
firth group gathers the following concepts (Bowen et al., 2001; Fiksel, 2003; Kleindorfer et al., 2005; Svensson, 2007; Srivastava, 2007), which reinforces the theoretical foundations of the green chain category both in processes and product-services design, which determines a consolidated approach to this approach of sustainable supply chains. This represents a stage, which expresses sustainability through technical, organizational, and engineering aspects, which according to Ahi and Searcy (2013) is a theoretical construct that brings together a practical and scientific value in the framework of the sustainable supply chain.

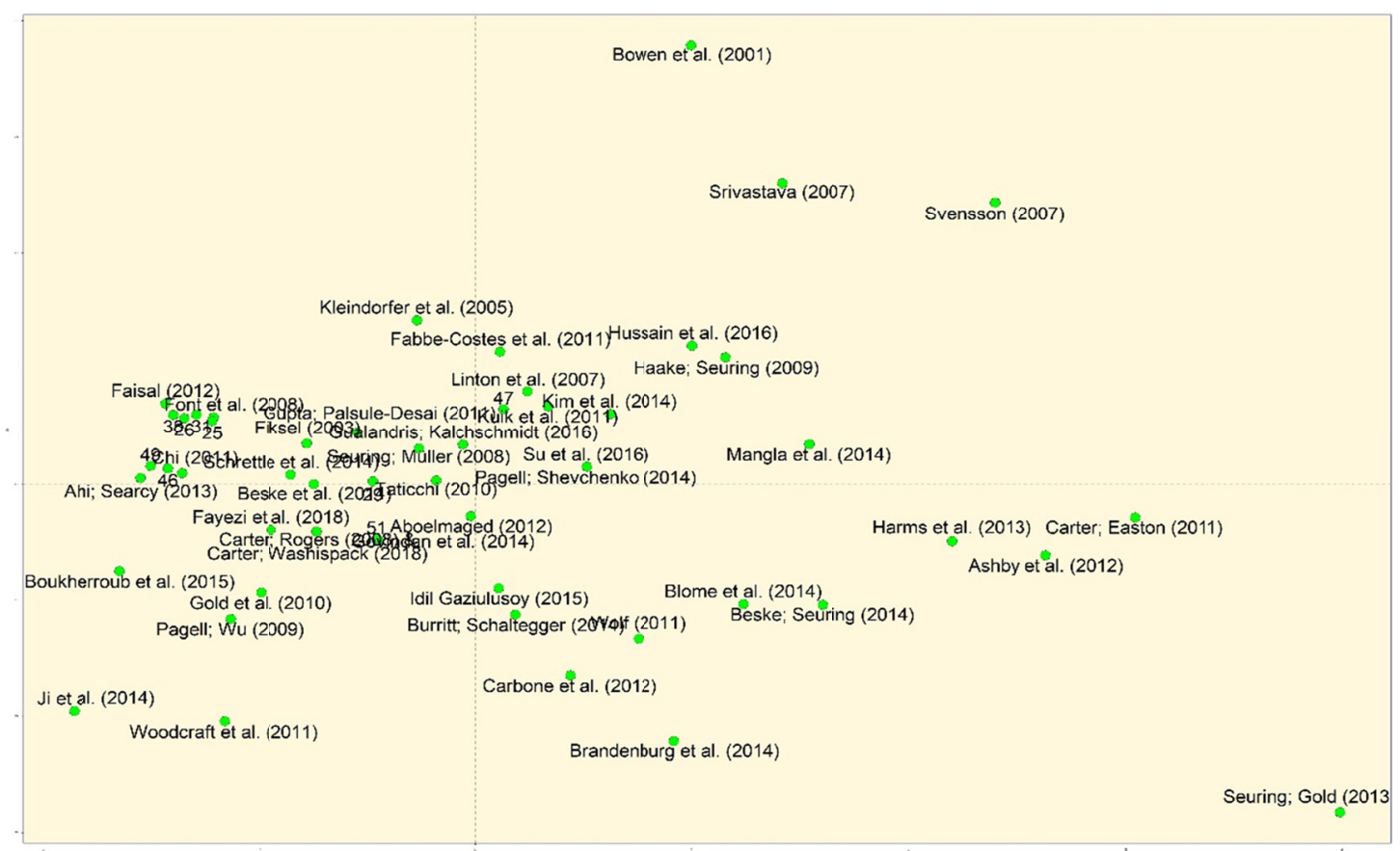

Figure 4. Multidimensional scaling of the sample of concepts: (25) Gunasekaran; Spalanzani (2012), (26) Hassini et al. (2012), (29) Hansen; Schaltegger (2013), (31) Muduli; Barve (2013), (38) Gualandris; Kalchschmidt (2014), (46) Kannegiesser et al. (2015), (47) Tajbakhsh; Hassini (2015), (49) Hsu et al. (2016) and (51) Matthews et al. (2016)

For its part, the most relevant group, according to the number of interconnected concepts and the bibliometric indexes consulted are in: Fiksel (2003), Linton et al. (2007), Carter and Rogers (2008), Seuring and Müller (2008), Haake and Seuring (2009), Pagell and Wu (2009), Gold et al. (2010), Taticchi (2010), Fable-Costes et al. (2011), Kuik et al. (2011), Wolf (2011), Gupta and Palsule-Desai (2011), Aboelmaged (2012), Hansen and Schaltegger (2013), Beske et al. (2014), Govindan et al. (2014), Gualandris and Kalchschmidt (2014), Kim et al. (2014), Pagell and Shevchenko (2014), Schoettle et al. (2014), Tajbakhsh and Hassini (2015), Gualandris and Kalchschmidt (2016), Su et al. (2016), Carter and Washispack (2018), Fayezi et al. (2018), which represent the second group. This group proposes a sustainability orientation to the role of the actors in the chain that can integrate the strategic-tactical-operational levels in the management system. However, the proposal of Matthews et al. (2016), which belongs to this group, is discussed the paradox about the applicability of the sustainability approach at the supply chain level that represents a limited practice in the analysis.

The third group is determined by the concepts (Font et al., 2008; Chi, 2011; Gunasekaran \& Spalanzani, 2012; Elkafi Hassini et al., 2012; Faisal, 2012; Muduli \& Barve, 2013; Ahi \& Searcy, 2013a; Gualandris \& Kalchschmidt, 2014; Kannegiesser et al., 2015; Hsu et al., 2016), which are focused on the priority issues of to apply sustainability in the different supply chain scenarios. The priorities here are represented in a combination of study objects, be they processes and products, to obtain the integration of management levels, and to allow models of performance evaluation.

The concepts that explore issues of boundaries between the actors in the chain define the fourth group. In the fourth group, the external factors are that have higher weight such as a system of pressure and reward the stakeholders, which require results for each actor at each moment of resource exchange along the supply chain. 
The concepts that are comprised: Woodcraft et al. (2011), Ji et al. (2014), Boukherroub et al. (2015), that do not share the similarity in factors and priority, but that consider the performance of suppliers and the life cycles of goods, as elements of different dimensions that contribute to the category under analysis.

For its part, a group cannot be assigned by similarity criteria or is represented by Carbone et al. (2012), Burritt and Schaltegger (2014), Idil Gaziulusoy (2015), Brandenburg et al. (2014). The contribution that these concepts give to the definition of a sustainable supply chain is an approach that relates corporate responsibility, holistic decision support models, comparisons between weak and strong sustainability in the supply chain context.

Finally, there are the fifth group of concepts are composed by Carter and Easton (2011), Ashby et al. (2012), Stefan Seuring and Gold (2012), Harms et al. (2013), Blome et al. (2014), Beske and Seuring (2014), Mangla et al. (2014), that in favor of the proposed definition's reference is made to sustainability through the contributions of internal strategies, risk management, creation of corporate and sustainable competitiveness. This group corresponds to a certain extent to the actors of the supply chain with a strong orientation to local circumstances, according to each case of study, which must be considered in the barriers to measuring performance.

In this way, the mapping of the approaches of the category allows to response to Q1, the conceptual structures, either by the semantic evaluation and/or multidimensional scaling according to the arguments exposed is defined by concepts that are oriented to environmental, economic, and social issues within a predominance of triple bottom line theory. However, this condition may change the weight of these structures if the concepts align themselves to issues such as natural resources-based view, dynamic capabilities, relational, stakeholder, institutional or transaction cost savings, which leads us to an understanding of each concept, which results in a characteristic scope of this category.

For the multidimensional scaling vertical orientation and horizontal is define as the particularity to share among the concepts. The $\mathrm{D}_{1}$ of vertical orientation is defined as a degree of expressive particularity of the concepts, i.e., the concepts may present a general perspective or focus on the actors, processes, or functions within the context of the chain, and in response to the prevailing theory. The $\mathrm{D}_{2}$ of horizontal orientation is defined as the relative evolution of concepts, which expresses the incorporation of elements as the reason for the category's reach. The evidence exposed by the superposition between $D_{1} \times D_{2}$ demarcates a certain degree of divergence on the definition of a sustainable supply chain.

The comparative dimensions in the multidimensional scaling can help in the answer at $\mathrm{Q}_{2}$, which it represents for the availability of an indicators system to attend the measurement of sustainable performance. Given this, the analyses carried out to declare the conceptual structure it is represented the availability of theoretical constructs, which is recognized by the academic and scientific community over the sustainable supply chain category.

\subsection{Intellectual - the Social Structure of the Studies Sampled}

The intellectual—social structure that corresponds to the studies and that sustains the concepts and enables a review of the academic community, researchers, institutions, and leaders of the study area. The characterization of the community and its relationship with the biases of the concepts offers an argumentative perspective on the collaborative networks that can be presented in the selected sample. The elements that are considered are the analysis of the social structure through authors, co-authors, institutions, sources of funding, and the citations made by the articles, which allows defining certain common points that contribute to and condition the formulations of the concepts in each study.

For these analyses, a query is performed in ISI-Web of Science and Scopus, which define the metadata of each of the articles of the sample. From this dataset, you can establish the network of co-authors that gathers the research groups of the sample. The network of co-authors makes it possible to define the most influential researchers in this category. This allows demarcating the schools of thought and biases valued over the category, expressive by a research group. Besides, the most renowned institutions can be defined according to the number of publications versus levels of citations per document published. Given this, the statement of the conceptual dimensions that are associated with each cluster of the network can provide the evidence to relate to the theoretical framework and the existing barriers in measuring sustainable performance in supply chain actors.

The intellectual structure began with the evaluation of citations and quotations that correspond to the articles studied. In this case, the intellectual structure is determined by a citation system that presents the following result: 


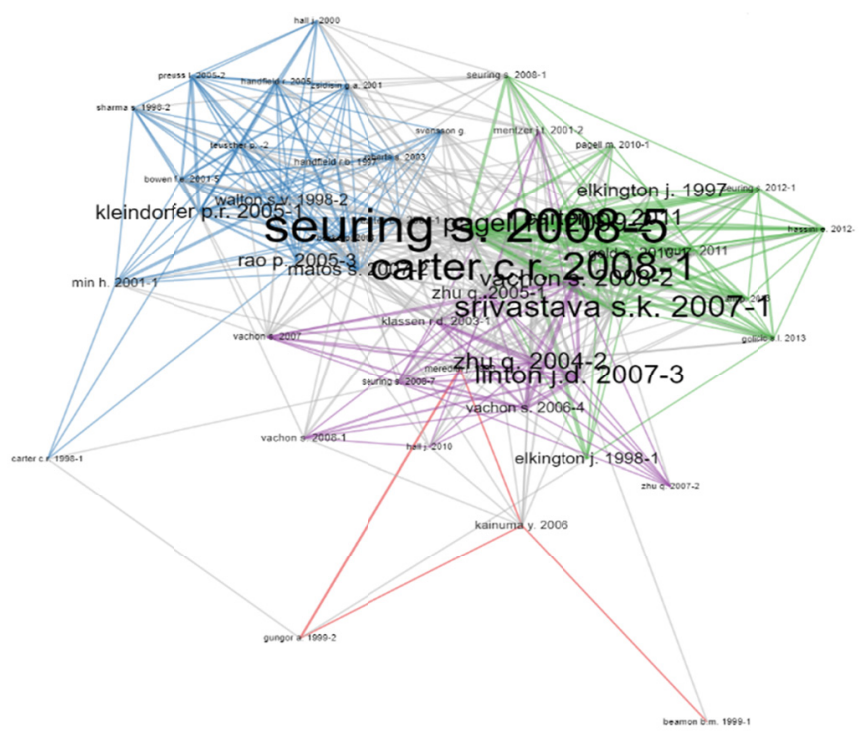

Figure 5. Bibliographic coupling of the sample

The most relevant references are determined by the studies of Srivastava (2007), Seuring and Müller (2008), Carter and Rogers (2008), Pagell and Wu (2009), each one belongs to the selected sample. The concepts derived from these studies are between groups one and two, which were analyzed in the conceptual structure. The intellectual structure corroborates in favor of the co-citation system of the four groups expressed in the conceptual structure. This evaluation has been carried out through the citation system by authors, which results in, (See Table 2).

Table 2. Ranking of citations by authors and co-authors

\begin{tabular}{lll}
\hline No & Authors & Citations \\
\hline 1. & Sarkis J & 109 \\
2. & Seuring S & 109 \\
3. & Carter C R & 84 \\
4. & Klassen R D & 84 \\
5. & Zhu Q & 62 \\
6. & Vachon S & 49 \\
7. & Pagell M & 48 \\
8. & Van Wassenhove L N & 45 \\
9. & Schaltegger S & 38 \\
10. & Muller M & 33 \\
11. & Jayaraman V & 31 \\
12. & Wu Z & 30 \\
13. & Preuss L & 25 \\
14. & Elkington J & 24 \\
15. & Rogers D S & 24 \\
16. & Linton J D & 23 \\
17. & Kleindorfer P R & 22 \\
18. & Lamming R C & 22 \\
19. & Shankar R & 22 \\
\hline
\end{tabular}

The nineteen most important authors according to the sample can be considered as leaders of the intellectual structure, the authors, and co-authors of three of the four most cited references are in this group of higher weight. This allows us to conclude that the theoretical framework is determined by a knowledge management base that is defined by a system of cooperation between researchers, which represents by the category the consolidation of the groups of works. Based on these results, the social structure must be evaluated and thus confirm the collaborative networks of researchers and the institutions that contribute the most in the sample to the social structure of this category. 
In the evaluation of the social structure, the relationship between authors and co-authors in revised documents and the institutions of these researchers was considered. The indicator related to the researchers, which is expressed by the existing networks of collaboration has been shared for document numbers: Seuring, S. (7), Carter, C. R. (3), Beske, P. (3) and Schaltegger, S. (3), which is reiterative in certain cases to the authors of the most prominent articles previously cited.

The most important institutions define conditions that may vary over time, according to the association of researchers with the employment relationship or projects at the time of publication. Among the most relevant institutions are: University of Kassel (14), University of Nevada (5), Arizona State University (3), Ryerson University (3), Indian Institute of Technology (3), and Universität Lüneburg (3), with a possible condition of two or more researchers per institution.

The interpretation of this state presented in the sample about the social structure summarizes that approximately 25 of the 54 documents are the results of a collaborative network that combines researchers and institutions in common. The result is that the theoretical framework can count on centrality in the academic system-research, according to the sample, and that they contribute to the object of study and can affect the development of new concepts.

Given this, the review of conceptual, intellectual-social structures shows that the sustainable supply chain in favor of content, the relationships of research, quotes, and collaborative networks are defined by multiple dimensions, those that express a relationship with the different levels that make up the chain, which determines different conditions and areas of interest according to reference analysis and concepts consulted.

\subsection{Building a Sustainable Supply Chain Management Concept}

The literature review and corresponding evaluation of the sample may demarcate an adequate position to build a conceptual map. The objective is to respond to the $\mathrm{Q}_{3}$ to conclude the descriptive framework on the role of the selected theories in the theoretical framework about the concept of the sustainable supply chain. To accomplish this type of construction is considered the premise that each one of the studied concepts is an advance to this category, but a certain group proposes conceptual maps that are based on the underlying theories. This step gathers all elements to conclude a consensus in the form of a concept and thus delimit the existing lacks, at least in the theoretical order, in the measurement of sustainable performance in actors of the chain, which represents the contribution to the general objective of this study.

As a response to $\mathrm{Q}_{3}$, derived from the previous study of conceptual maps and the concepts of the sample, it defines that the models that are oriented to environmental management issues present a greater weight for the theories: natural resources-based view, dynamic capabilities, and transaction cost savings, with a lower weight for stakeholder theory. The green supply chain concepts include the relational and institutional theories, besides those considered by the previous stage. Finally, the sustainable supply chain combines in most cases a relevant weight for each of the theories considered, especially the triple bottom line theory. This response to $\mathrm{Q}_{3}$, but it is important to recognize that the complexity arising from the broad concept of the sustainable supply chain can bind other theoretical formulations, a question that is outside the objectives of this study.

The construction of a concept is defined that it is dispensable to pass through the consideration of the environmental dimension in all its extension. In this case, the environmental dimension does not present a single theory that explains the direct and indirect relationship between the actors of a value chain. For this reason, the relations of environmental issues face the following theories: natural resources-based view, dynamic capabilities, relational, stakeholder, triple bottom line, institutional and transaction cost savings, is an essential dimension to assign the sustainable approach to any supply chain.

At this point, the elements are determined by the question of the sustainable bias, which is represented by the sums of the results of all the actors or individual players of the supply chain. This question can be explained by the socioeconomic dimension, which represents a system of pressure and rewards for action at the different levels of the chain (Seuring \& Müller, 2008), which should be based on the focal unit. Certain behaviors to be become a set of triggers of the sustainable performance, either through the selection of suppliers, attention to internal or external social groups, or compliance with the legal norms where it develops these activities. This expresses a benchmark for the following theories: relational, stakeholder, triple bottom line, institutional, and that closes the macros - dimensions of the sustainable supply chain concept as a requirement at actors.

The separation by groups of factors within socioeconomic may define a scheme of interests at the macro and micro levels that has an unfolding to those under political-cultural, technical-technological, etc. dimensions. However, social factors have been recognized as the neediest group of factors in the modeling perspective 
(Brandenburg et al., 2014; Brandenburg \& Rebs, 2015; Kannan Govindan et al., 2015), which is recognized in stakeholder, triple bottom line, and institutional theories. The conditions that were exposed by Ehrgott et al. (2011), Ahmadi et al. (2017) over the social factors manifest themselves as a barrier at different levels of sustainability management in the supply chain context because can be expressive of the performance of the chain actors. For their part, economic factors present a predominant condition, both in concepts and conceptual maps, which allows for a balance between environmental and economic in measurement of sustainable performance.

Conceptual maps consider and reflect a system of dimensions general which must be analyzed through a sample of the conceptual maps. The conceptual maps such as: Bowen et al. (2001), Seuring and Müller (2008), Carter and Rogers (2008), Pagell and Wu (2009), Gold et al. (2010), Chi (2011), Fabbe-Costes et al. (2011, 2014), Hsu et al. (2016), Fayezi et al. (2018), may define within the selected sample the graphic expressiveness of some sustainable supply chain studies. These conceptual maps represent a significant reduction of the studies initially, but analysis of the conceptual maps can be used. For the construction of a conceptual map, a critique of each of the mentioned models is made, which results in a characterization of the weights of each theory in them and derived from this the existing barriers to measuring sustainable performance in actors of the supply chain. To build the concept through the valuation of the mentioned models may be defined. The criteria are used, besides the correspondence of the mentioned theories, the points of incidence in the supply chain and how sustainability is considered in each case and its relation to the performance of the actor. The results of this evaluation of the conceptual maps are summarized in, (See Table 3).

The results of the evaluation of the conceptual maps define that the sustainable supply chain category presents evolution because of the problems addressed over the last years, in these conceptual maps. To build a concept seen at the points of incidence in the chain and the scope of the sustainability biases in each of the models, it is adopted in this study that:

Sustainable supply chain is the assignment given to management levels that aim at a transfer of goods and services with a favorable relationship for the stakeholders by the principle of balance between the dimension's rules sustainable performance.

The concepts that have most influenced this demarcation are Seuring and Müller (2008), Carter and Rogers (2008), Fabbe-Costes et al. (2011) with the contributions made from environmental management and green supply chain, which also were considered by the sample studies. Given this, the barriers to measuring sustainable performance in supply chain actors are conditioned for several causes, which is not reflexed in the concept was cited. The comprehensive framework of indicators and quantities that can characterize sustainable performance and that is particular to each case study is the point starting to define the barriers of the measurement of sustainable performance. 
Table 3. Descriptive table on the conceptual maps

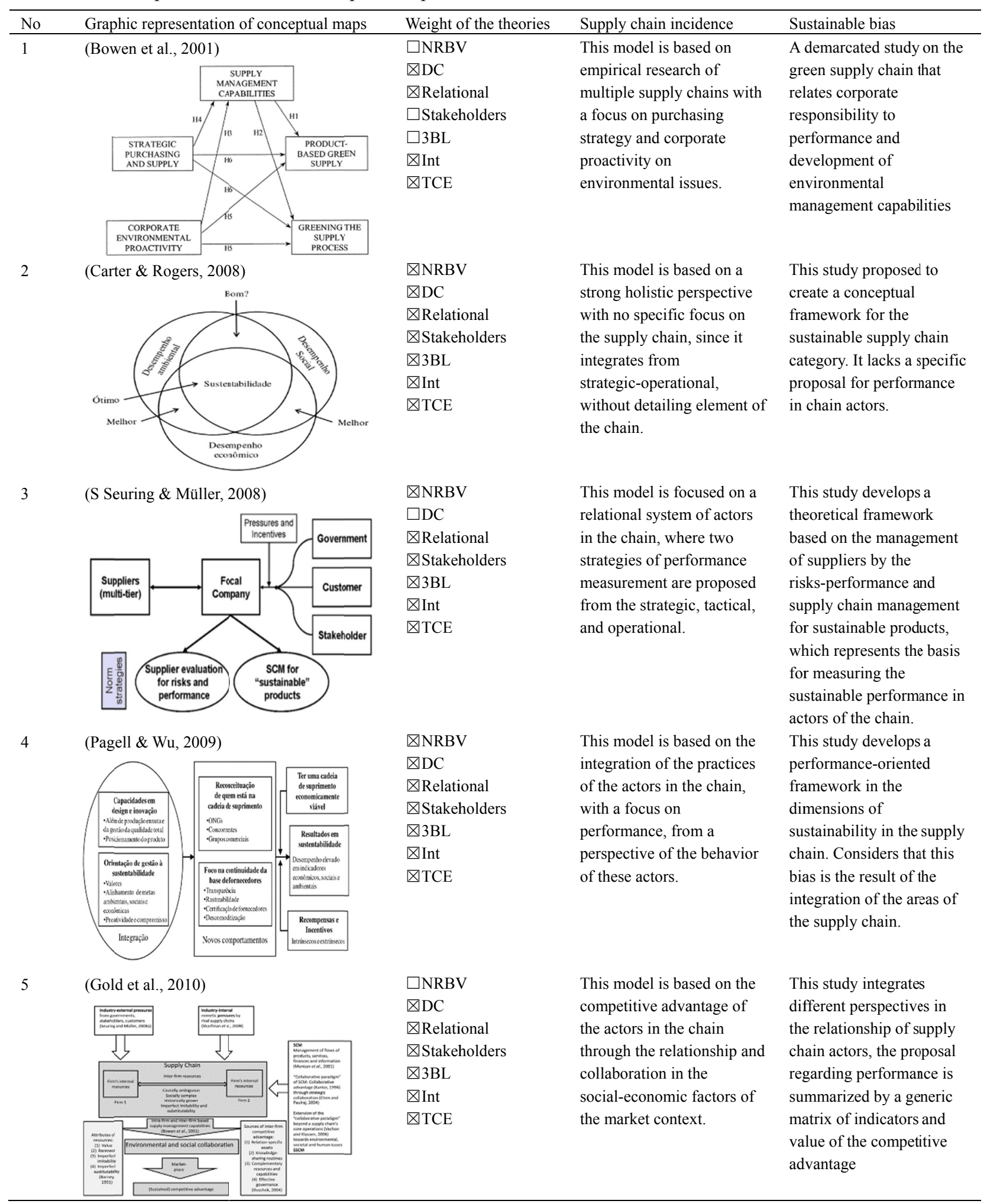




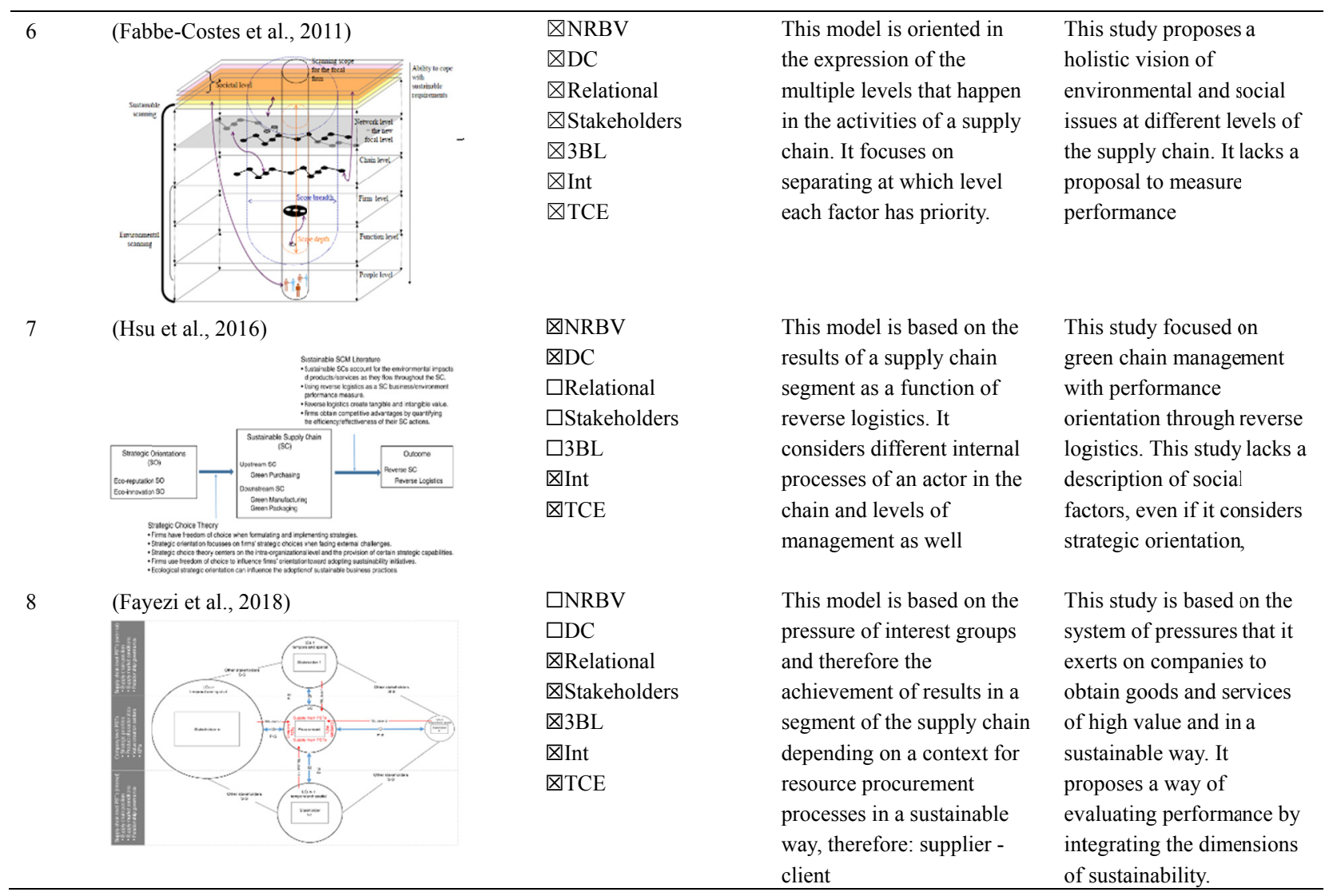

Note. NRBV: Natural resources-based view theory; DC: Dynamic capabilities theory; Relational: Relational theory; Stakeholders: Stakeholder theory; 3BL: Triple bottom line theory; Int: Institutional theory; TCE: Transaction cost economic theory.

\section{Barriers to Measuring Performance}

The answer to each of the questions formulated at the outset of the study can help identify the barriers to sustainable performance measurement, which will be assessed in this part of the study. According to the concept assumed about sustainable supply chain where attention to management levels in chain agents can affect the logistics network, strategies, and internal culture of these agents. Faced with this, defining the ability to measure sustainable performance depends on what the scope of this measurement is. This relative condition of the measurement process begins in the design of the planning and organization of the processes in the agents, this implies a detailed study of the integrated management system to minimize impacts and maximize returns, which can be noted differently in the conceptual maps evaluated (Bowen et al., 2001; Seuring \& Müller, 2008; Carter \& Rogers, 2008; Pagell \& Wu, 2009; Gold et al., 2010; Chi, 2011; Fabbe-Costes et al., 2011, 2014; Hsu et al., 2016; Fayezi et al., 2018).

The barriers to measuring sustainable performance are evident in conditions that identify the lack of a development projection based on innovation and conservation of natural resources. This manifestation is recurrent mostly in regions or countries where the rules of protection of environmental assets and compliance with socioeconomic rights are not declared or if it is vacillating in their control. Seeking a way to measure sustainability in agents of the chain in these mentioned conditions is complex and little recommended. The lack of a sectorial strategy, of local activism or groupings of stakeholders around the agents in analyses, is the worst condition to start measuring sustainable performance.

Another barrier that may manifest itself is the lack of independent bodies to the powers of the agents in the chain to manage and certify metrology and the quality of goods and services. In this case, even when in the socio-economic and environmental plan there is evidence of intent to change, and the rules are declared, independent control institutions are needed. The conditions for measuring sustainable performance, in this case, are nothing more than an evaluation of culture and responsibility without being able to define sensitive indicators of each activity in the order of physical and chemical properties, to cite some examples.

The lack of mastery of the concept of sustainability establishes itself as a barrier to measurement, which is 
evident in the applicability of the concept of sustainability. In this case, the causes lie in the powers of the decision-makers involved, since there is a degree of intensity to declare sustainable from a biocentric to strong anthropocentric bias (Daly, 2005), which are divergent among them. This is a condition that can be tangency to define training protocols and models for measuring sustainable performance.

The recognition by studies (Seuring, 2013; Brandenburg et al., 2014; Brandenburg \& Rebs, 2015) of the existing barriers in the methods for measuring social factors also affects an estimate of performance. These factors are present at each management level and support changes in the practice models of the agents in the chain. The causes of this condition are the lack of theories to address these factors and their complexity to assign a performance metric. Nevertheless, in the conceptual map of Fayezi et al. (2018) a solution is proposed to integrate the variables that partially represent the social factors.

Finally, a barrier that is evident in concept studies is the lack of an integrated theory to designate a sustainable supply chain. An integrated theory is the desired condition to explain this category, either globally, by types of chains or by specific agents, the characteristic elements of sustainability in each case. The proposals of the concept of Base of the Pyramid (BoP) help in this sense, Prahalad and Hart (2002) and Prahalad and Hammond (2002) as a reference to weigh the economic, social and environmental ones that condition the model of action of the units of decision making. This approach is recognized and promoted by Gold et al. (2013), Stefan Seuring and Gold (2013), Kolk et al. (2014) and Khalid et al. (2015), as a response to existing theoretical constraints in this area. Given this, it can be defined that as concepts and conceptual maps develop to explain sustainability in supply chains, we find certain barriers to measuring performance, which represents a condition of evolution and the search for new knowledge

\section{Discussion}

The theoretical framework over the sustainable supply chain is defined by the academic and research work in multiple areas of knowledge. The empirical research, modeling, theoretical and conceptual maps can define a concept about this category. The declaration of the conceptual constructs in eight conceptual maps was considered, which represents a relevant point in the concept implementation. The scope of these constructs depends on the context and point of incidence in the supply chain, which may represent a direct and/or indirect link between planning systems, risk management, stakeholder pressure, and key performance indicators, which is an issue to be treated in studies future. Nevertheless, in the revision of concepts through conceptual-institutional-social structures were identified the barriers to the measurement of sustainable performance as a certain limitation of this approach. It is concluded that the results to establish the barriers of measurement of sustainable performance in actors of the chain are limited to assess the outcomes in different structures and infrastructures of the supply chain. For this reason, the root of the barriers to measuring sustainable performance, which was described, can have several origins that represent the justification for new inquiries. The practical constraints demand that being proposal or adapt the management methods to surpass these barriers in measurement of sustainable performance.

\section{Conclusion}

The literature review conducted allows us to conclude from the state of the art of sustainable supply chain concepts to the identification of certain barriers to measuring performance. The provision of a conceptual framework for designating sustainability at different levels of the supply chain is evident from the sample studied. The concepts analyzed present common factors through the environmental and socioeconomic dimensions, which are key in the application of the theories considered. The concept maps analyzed combine a varied theoretical system that responds to the evolution of the category under consideration. The existing barriers in the measurement of sustainable performance depend on multiple causes and generate a negative effect on the relevance of this concept. Future studies should follow the progress of available methods or the formulation of integrated theory to connect each phase of the management cycle.

\section{Acknowledgments}

This study was financed in part by the "Coordenação de Aperfeiçoamento de Pessoal de Nível Superior Brasil" (CAPES) Finance Code 001.

\section{Authors' Contributions}

The conceptualization of the research article was realized by A. Pérez-Velázquez. The Research methodology was selected by A. Pérez-Velázquez with a review of J.L. Moya-Rodríguez. The literature review was realized by A. Pérez-Velázquez. The validation of results was developed by A. Pérez-Velázquez and J.L. Moya-Rodríguez. The form analysis, investigation, and writing-original draft preparation was the responsibility of A. 
Pérez-Velázquez and J.L. Moya-Rodríguez. The writing - review and editing, supervision, and funding acquisition were responsible by J.L. Moya-Rodríguez; and task management results of the study was the responsibility of A. Pérez-Velázquez and J.L. Moya-Rodríguez.

\section{Conflict of Interest}

The authors declare no conflict of interest in the study

\section{References}

Aboelmaged, M. G. (2012). Sustainable supply chain management in a developing context: An empirical examination of antecedents and consequences. International Journal of Social Ecology and Sustainable Development, 3(3), 22-41. https://doi.org/10.4018/jsesd.2012070103

ACETIC-CYBERLEX, \& Investors private. (2020). Semantic-Knowledge.

Ahi, P., \& Searcy, C. (2013). A comparative literature analysis of definitions for green and sustainable supply chain management. Journal of Cleaner Production, 52, 329-341. https://doi.org/10.1016/j.jclepro.2013.02.018

Ahmadi, H. B., Kusi-sarpong, S., \& Rezaei, J. (2017). Assessing the social sustainability of supply chains using Best Worst Method. Resources, Conservation \& Recycling, 126(May), 99-106. https://doi.org/10.1016/j.resconrec.2017.07.020

Ansari, Z. N., \& Kant, R. (2017). A state-of-art literature review reflecting 15 years of focus on sustainable supply chain management. Journal of Cleaner Production, 142, 2524-2543. https://doi.org/10.1016/j.jclepro.2016.11.023

Ashby, A., Leat, M., \& Hudson-Smith, M. (2012). Making connections: A review of supply chain management and sustainability literature. Supply Chain Management, 17(5), 497-516. https://doi.org/10.1108/13598541211258573

Beske, P., Land, A., \& Seuring, S. (2014). Sustainable supply chain management practices and dynamic capabilities in the food industry: A critical analysis of the literature. International Journal of Production Economics, 152, 131-143. https://doi.org/10.1016/j.ijpe.2013.12.026

Beske, P., \& Seuring, S. (2014). Putting sustainability into supply chain management. Supply Chain Management: An International Journal, 19(3), 322-331. https://doi.org/10.1108/SCM-12-2013-0432

Blome, C., Paulraj, A., \& Schuetz, K. (2014). Supply chain collaboration and sustainability: A profile deviation analysis. International Journal of Operations and Production Management, 34(5), 639-663. https://doi.org/10.1108/IJOPM-11-2012-0515

Boukherroub, T., Ruiz, A., Guinet, A., \& Fondrevelle, J. (2015). An integrated approach for sustainable supply chain planning. Computers and Operations Research, 54, 180-194. https://doi.org/10.1016/j.cor.2014.09.002

Bowen, F. E. E., Cousins, P. D., Lamming, R. C. C., \& Faruk, A. C. C. (2001). The role of supply management capabilities in green supply. Production and Operations Management, 10(2), 174-189. https://doi.org/10.1111/j.1937-5956.2001.tb00077.x

Brandenburg, M., Govindan, K., Sarkis, J., \& Seuring, S. (2014). Quantitative models for sustainable supply chain management: Developments and directions. European Journal of Operational Research, 233(2), 299-312. https://doi.org/10.1016/j.ejor.2013.09.032

Brandenburg, M., \& Rebs, T. (2015). Sustainable supply chain management: a modeling perspective. Annals of Operations Research, 229(1), 213-252. https://doi.org/10.1007/s10479-015-1853-1

Brundtland, G., Khalid, M., Agnelli, S., Al-Athel, S., Chidzero, B., Fadika, L., ... de Botero, M. M. (1987). Our common future.

Burritt, R., \& Schaltegger, S. (2014). Accounting towards sustainability in production and supply chains. British Accounting Review, 46(4), 327-343. https://doi.org/10.1016/j.bar.2014.10.001

Carbone, V., Moatti, V., \& Vinzi, V. E. (2012). Mapping Corporate Responsibility and Sustainable Supply Chains: An Exploratory Perspective. Business Strategy and the Environment, 21(7), 475-494. https://doi.org/10.1002/bse.1736

Carter, C. R., \& Easton, P. L. (2011). Sustainable supply chain management: evolution and future directions. International Journal of Physical Distribution and Logistics Management, 41(1), 46-62. 
https://doi.org/10.1108/09600031111101420

Carter, C. R., Hatton, M. R., Wu, C., \& Chen, X. (2019). Sustainable supply chain management: continuing evolution and future directions. International Journal of Physical Distribution and Logistics Management, 50(1), 122-146. https://doi.org/10.1108/IJPDLM-02-2019-0056

Carter, C. R., \& Rogers, D. S. (2008). A framework of sustainable supply chain management: Moving toward new theory. International Journal of Physical Distribution \& Logistics Management, 38(5), 360-387. https://doi.org/10.1108/09600030810882816

Carter, C. R., \& Washispack, S. (2018). Mapping the Path Forward for Sustainable Supply Chain Management: A Review of Reviews. Journal of Business Logistics, 39(4), 242. https://doi.org/10.1111/jbl.12196

Chi, T. (2011). Building a sustainable supply chain: An analysis of corporate social responsibility (CSR) practices in the Chinese textile and apparel industry. Journal of the Textile Institute, 102(10), 837-848. https://doi.org/10.1080/00405000.2010.524361

Cigolini, R., Cozzi, M., \& Perona, M. (2004). A new framework for supply chain management. Conceptual model and empirical test. International Journal of Operations and Production Management, 24(1), 7-41. https://doi.org/10.1108/01443570410510979

Cooper, M. C., Lambert, D. M., \& Pagh, J. D. (1997). Supply Chain Management: More Than a New Name for Logistics. International Journal of Logistics Management, 8(1), 1-14. https://doi.org/10.1108/09574099710805556

Daly, H. E. (2005). Economics in a full world. IEEE Engineering Management Review, 33(4), 21-29. https://doi.org/10.1109/EMR.2005.27010

Ehrgott, M., Reimann, F., Kaufmann, L., \& Carter, C. R. (2011). Social Sustainability in Selecting Emerging Economy Suppliers. Journal of Business Ethics, 98(1), 99-119. https://doi.org/10.1007/s10551-010-0537-7

Fabbe-Costes, N., Roussat, C., \& Colin, J. (2011). Future sustainable supply chains: What should companies scan? International Journal of Physical Distribution \& Logistics Management, 41(3), 228-252. https://doi.org/10.1108/09600031111123778

Fabbe-Costes, N., Roussat, C., Taylor, M., \& Taylor, A. (2014). Sustainable supply chains: A framework for environmental scanning practices. International Journal of Operations and Production Management, 34(5), 664-694. https://doi.org/10.1108/IJOPM-10-2012-0446

Faisal, M. N. (2012). Sustainability metrics for a supply chain: The case of small and medium enterprises. International Journal of Services and Operations Management, 13(3), 392-414. https://doi.org/10.1504/IJSOM.2012.049710

Fayezi, S., Zomorrodi, M., \& Bals, L. (2018). Procurement sustainability tensions: An integrative perspective. International Journal of Physical Distribution and Logistics Management, 48(6), 586-609. https://doi.org/10.1108/IJPDLM-01-2017-0013

Fiksel, J. (2003). Designing Resilient, Sustainable Systems. Environmental Science and Technology, 37(23), 5330-5339. https://doi.org/10.1021/es0344819

Font, X., Tapper, R., Schwartz, K., \& Kornilaki, M. (2008). Sustainable supply chain management in tourism. Business Strategy and the Environment, 17(4), 260-271. https://doi.org/10.1002/bse.527

Geng, R., Mansouri, S. A., \& Aktas, E. (2017). The relationship between green supply chain management and performance: A meta-analysis of empirical evidences in Asian emerging economies. International Journal of Production Economics, 183, 245-258. https://doi.org/10.1016/j.ijpe.2016.10.008

Gold, S., Hahn, R., \& Seuring, S. (2013). Sustainable supply chain management in "Base of the Pyramid" food projects-A path to triple bottom line approaches for multinationals? International Business Review, 22(5), 784-799. https://doi.org/10.1016/j.ibusrev.2012.12.006

Gold, S., Seuring, S., \& Beske, P. (2010). Sustainable supply chain management and inter-organizational resources: A literature review. Corporate Social Responsibility and Environmental Management, 17(4). https://doi.org/10.1002/csr.207

Govindan, K., Jafarian, A., Khodaverdi, R., \& Devika, K. (2014). Two-echelon multiple-vehicle location-routing problem with time windows for optimization of sustainable supply chain network of perishable food. International Journal of Production Economics, 152(2009), 9-28. 
https://doi.org/10.1016/j.jpe.2013.12.028

Govindan, K., Rajendran, S., Sarkis, J., \& Murugesan, P. (2015). Multi criteria decision making approaches for green supplier evaluation and selection: A literature review. Journal of Cleaner Production, 98, 66-83. https://doi.org/10.1016/j.jclepro.2013.06.046

Gualandris, J., \& Kalchschmidt, M. (2014). Customer pressure and innovativeness: Their role in sustainable supply chain management. Journal of Purchasing and Supply Management, 20(2), 92-103. https://doi.org/10.1016/j.pursup.2014.03.001

Gualandris, J., \& Kalchschmidt, M. (2016). Developing environmental and social performance: The role of supplier's sustainability and buyer-supplier trust. International Journal of Production Research, 54(8), 2470-2486. https://doi.org/10.1080/00207543.2015.1106018

Gunasekaran, A., \& Spalanzani, A. (2012). Sustainability of manufacturing and services: Investigations for research and applications. International Journal of Production Economics, 140(1), 35-47. https://doi.org/10.1016/j.jpe.2011.05.011

Gupta, S., \& Palsule-Desai, O. D. (2011). Sustainable supply chain management: Review and research opportunities. IIMB Management Review, 23(4), 234-245. https://doi.org/10.1016/j.iimb.2011.09.002

Haake, H., \& Seuring, S. (2009). Sustainable procurement of minor items-Exploring limits to sustainability. Sustainable Development, 17(5), 284-294. https://doi.org/10.1002/sd.424

Hansen, E. G., \& Schaltegger, S. (2013). 100 per cent organic? A sustainable entrepreneurship perspective on the diffusion of organic clothing. Corporate Governance (Bingley), 13(5), 583-598. https://doi.org/10.1108/CG-06-2013-0074

Harms, D., Hansen, E. G., \& Schaltegger, S. (2013). Strategies in sustainable supply chain management: An empirical investigation of large german companies. Corporate Social Responsibility and Environmental Management, 20(4), 205-218. https://doi.org/10.1002/csr.1293

Hassini, E., Surti, C., \& Searcy, C. (2012). A literature review and a case study of sustainable supply chains with a focus on metrics. International Journal of Production Economics, 140(1), 69-82. https://doi.org/10.1016/j.ijpe.2012.01.042

Hsu, C. C., Tan, K. C., \& Mohamad Zailani, S. H. (2016). Strategic orientations, sustainable supply chain initiatives, and reverse logistics: Empirical evidence from an emerging market. International Journal of Operations and Production Management, 36(1), 86-110. https://doi.org/10.1108/IJOPM-06-2014-0252

Hussain, M., Khan, M., \& Al-Aomar, R. (2016). A framework for supply chain sustainability in service industry with Confirmatory Factor Analysis. Renewable and Sustainable Energy Reviews, 55, 1301-1312. https://doi.org/10.1016/j.rser.2015.07.097

Hutchins, M. J., \& Sutherland, J. W. (2008). An exploration of measures of social sustainability and their application to supply chain decisions. Journal of Cleaner Production, 16(15), 1688-1698. https://doi.org/10.1016/j.jclepro.2008.06.001

Idil Gaziulusoy, A. (2015). A critical review of approaches available for design and innovation teams through the perspective of sustainability science and system innovation theories. Journal of Cleaner Production, 107, 366-377. https://doi.org/10.1016/j.jclepro.2015.01.012

Ji, G., Gunasekaran, A., \& Yang, G. (2014). Constructing sustainable supply chain under double environmental medium regulations. International Journal of Production Economics, 147(PART B), 211-219. https://doi.org/10.1016/j.jpe.2013.04.012

Kannegiesser, M., Günther, H. O., \& Autenrieb, N. (2015). The time-to-sustainability optimization strategy for sustainable supply network design. Journal of Cleaner Production, 108, 451-463. https://doi.org/10.1016/j.jclepro.2015.06.030

Khalid, R. U., Seuring, S., Beske, P., Land, A., Yawar, S. A., \& Wagner, R. (2015). Putting sustainable supply chain management into base of the pyramid research. Supply Chain Management, 20(6), 681-696. https://doi.org/10.1108/SCM-06-2015-0214

Kim, K., Jeong, B., \& Jung, H. (2014). Supply chain surplus: Comparing conventional and sustainable supply chains. Flexible Services and Manufacturing Journal, 26(1-2), 5-23. https://doi.org/10.1007/s10696-012-9163-2 
Kleindorfer, P. R., Singhal, K., \& Van Wassenhove, L. N. (2005). Sustainable operations management. $\begin{array}{llll}\text { Production } \quad \text { Ond } & \text { Management, } & \text { 14(4), }\end{array}$ https://doi.org/10.1111/j.1937-5956.2005.tb00235.x

Kolk, A., Rivera-santos, M., \& Rufin, C. (2014). Reviewing a Decade of Research on the "Base/ Bottom of the Pyramid" (BOP) Concept. Business \& Society, 53(3), 338-377. https://doi.org/10.1177/0007650312474928

Kuik, S. S., Nagalingam, S. V., \& Amer, Y. (2011). Sustainable supply chain for collaborative manufacturing. Journal of Manufacturing Technology Management, 22(8), 984-1001. https://doi.org/10.1108/17410381111177449

Lambert, D. M., Cooper, M. C., \& Pagh, J. D. (1998). Supply Chain Management: Implementation Issues and Research Opportunities. The International Journal of Logistics Management, 9(2), 1-20. https://doi.org/10.1108/09574099810805807

Linton, J. D., Klassen, R., \& Jayaraman, V. (2007). Sustainable supply chains: An introduction. Journal of Operations Management, 25, 1075-1082. https://doi.org/10.1016/j.jom.2007.01.012

Luthra, S., Govindan, K., Kannan, D., Kumar, S., \& Prakash, C. (2017). An integrated framework for sustainable supplier selection and evaluation in supply chains. Journal of Cleaner Production, 140, 1686-1698. https://doi.org/10.1016/j.jclepro.2016.09.078

Maditati, D. R., Munim, Z. H., Schramm, H. J., \& Kummer, S. (2018). A review of green supply chain management: From bibliometric analysis to a conceptual framework and future research directions. Resources, Conservation and Recycling, 139, 150-162. https://doi.org/10.1016/j.resconrec.2018.08.004

Mangla, S. K., Kumar, P., \& Barua, M. K. (2014). Flexible decision approach for analysing performance of sustainable supply chains under risks/uncertainty. Global Journal of Flexible Systems Management, 15(2), 113-130. https://doi.org/10.1007/s40171-014-0059-8

Matthews, L., Power, D., Touboulic, A., \& Marques, L. (2016). Building Bridges: Toward Alternative Theory of Sustainable Supply Chain Management. Journal of Supply Chain Management, 52(1), 82-94. https://doi.org/10.1111/jscm.12097

Mayring, P. (2002). Einführung in die qualitative Sozialforschung eine Anleitung zu qualitativem Denken. Beltz.

Mayring, P. (2014). Qualitative Content Analysis Theoretical Foundation and Basic Procedures. Approaches to Qualitative Research in Mathematics Education, 365-380. https://doi.org/10.1007/978-94-017-9181-6_13

Mentzer, J. T., Dewitt, W., Keebler, J. S., Min, S., Nix, N. W., Smith, C. D., \& Zacharia, Z. G. (2001). Defining supply chain management. Journal of Business Logistics, 22(2), 1-25. https://doi.org/10.1002/j.2158-1592.2001.tb00001.x

Muduli, K., \& Barve, A. (2013). Sustainable development practices in mining sector: A GSCM approach. International Journal of Environment and Sustainable Development, 12(3), 222-243. https://doi.org/10.1504/IJESD.2013.054942

Pagell, M., \& Shevchenko, A. (2014). Why research in sustainable supply chain management should have no future. Journal of Supply Chain Management, 50(1), 44-55. https://doi.org/10.1111/jscm.12037

Pagell, M., \& Wu, Z. (2009). Building a more complete theory of sustainable supply chain management using case studies of 10 exemplars. Journal of Supply Chain Management, 45(2), 37-56. https://doi.org/10.1111/j.1745-493X.2009.03162.x

Porter, M. E., \& der Linde, C. (1995). Toward a new conception of the environment-competitiveness relationship. The Journal of Economic Perspectives, 9(4), 97-118. https://doi.org/10.1257/jep.9.4.97

Prahalad, C. K., \& Hammond, A. (2002). Serving the World's Poor, Profitably.

Prahalad, C. K., \& Hart, S. (2002). The fortune at the bottom of the pyramid. Strategy + Business.

Sarkis, J. (2012). A boundaries and flows perspective of green supply chain management. Supply Chain Management, 17(2), 202-216. https://doi.org/10.1108/13598541211212924

Schrettle, S., Hinz, A., Scherrer-Rathje, M., \& Friedli, T. (2014). Turning sustainability into action: Explaining firms' sustainability efforts and their impact on firm performance. International Journal of Production Economics, 147(PART A), 73-84. https://doi.org/10.1016/j.ijpe.2013.02.030

Seuring, S. (2013). A review of modeling approaches for sustainable supply chain management. Decision Support Systems, 54(4), 1513-1520. https://doi.org/10.1016/j.dss.2012.05.053 
Seuring, S., \& Gold, S. (2012). Conducting content-analysis based literature reviews in supply chain management. Supply Chain Management: An International Journal, 17(5), 544-555. https://doi.org/10.1108/13598541211258609

Seuring, S., \& Gold, S. (2013). Sustainable supply chain management in "Base of the Pyramid" food projects-A path to triple bottom line approaches for multinationals? Stefan. International Business Review, 22, 784-799. https://doi.org/10.1016/j.ibusrev.2012.12.006

Seuring, S., \& Müller, M. (2008). From a literature review to a conceptual framework for sustainable supply chain management. Journal of Cleaner Production, 16(15), 1699-1710. https://doi.org/10.1016/j.jclepro.2008.04.020

Srivastava, S. K. (2007). Green supply-chain management: A state-of-the-art literature review. International Journal of Management Reviews, 9(1), 53-80. https://doi.org/10.1111/j.1468-2370.2007.00202.x

Su, C. M., Horng, D. J., Tseng, M. L., Chiu, A. S. F., Wu, K. J., \& Chen, H. P. (2016). Improving sustainable supply chain management using a novel hierarchical grey-DEMATEL approach. Journal of Cleaner Production, 134(Part B), 469-481. https://doi.org/10.1016/j.jclepro.2015.05.080

Svensson, G. (2007). Aspects of sustainable supply chain management (SSCM): Conceptual framework and empirical example. Supply Chain Management: An International Journal, 12(4), 262-266. https://doi.org/10.1108/13598540710759781

Tajbakhsh, A., \& Hassini, E. (2015). Performance measurement of sustainable supply chains: A review and research questions. International Journal of Productivity and Performance Management, 64(6), 744-783. https://doi.org/10.1108/IJPPM-03-2013-0056

Taticchi, P. (2010). Business Performance Measurement and Management: New Contexts, Themes and Challenges. In Media. https://doi.org/10.1007/978-3-642-04800-5

Touboulic, A., \& Walker, H. (2015). Theories in sustainable supply chain management: A structured literature review. International Journal of Physical Distribution \& Logistics Management, 45(1/2), 16-42. https://doi.org/10.1108/IJPDLM-05-2013-0106

Tsoulfas, G. T., \& Pappis, C. P. (2008). A model for supply chains environmental performance analysis and decision making. Journal of Cleaner Production, 16(15), 1647-1657. https://doi.org/10.1016/j.jclepro.2008.04.018

Wolf, J. (2011). Sustainable Supply Chain Management Integration: A Qualitative Analysis of the German Manufacturing Industry. Journal of Business Ethics, 102(2), 221-235. https://doi.org/10.1007/s10551-011-0806-0

Woodcraft, S., Bacon, N., Caistor-Arendar, L., Hackett, T., \& Hall, P. (2011). Design for social sustainability: A framework for creating thriving new communities. Social Life, 54 .

\section{Copyrights}

Copyright for this article is retained by the author, with first publication rights granted to the journal.

This is an open-access article distributed under the terms and conditions of the Creative Commons Attribution license (http://creativecommons.org/licenses/by/4.0/). 